\title{
The subgingival microbial flora during pregnancy
}

\author{
KenNeth S. Kornman and Walter J. Loesche
}

Department of Microbiology, University of Michigan School of Medicine and Department of Oral Biology, University of Michigan School of Dentistry, Ann Arbor, Michigan, U.S.A.

The subgingival bacterial flora from 2 gingival sites was cultured and characterized monthly in twenty periodontitis-free women during pregnancy and again post-partum. Monthly plaque samples were also cultured in eleven age and disease matched non-pregnant women. Plaque was processed anaerobically on selective and nonselective media and the predominant colony types were characterized. A portion of each plaque sample was tested for bacterial uptake of C14-estradiol and C14-progesterone. Plasma levels of estrogens and progesterone were measured four times in each subject. The number of gingival bleeding sites, the Gingival Index and the Plaque Index were determined at each sampling period.

In the second trimester there was a significant increase in gingivitis, the ratio of anaerobic to aerobic bacteria, and the proportional levels of Bacteroides melaninogenicus ss. intermedius. In the third trimester both gingivitis and the levels of B. melaninogenicus ss. intermedius decreased. Plaque uptake of C14-steroids increased significantly during pregnancy and paralleled the plaque levels of $B$. melaninogenicus ss. intermedius. In the second trimester, recovery of $B$. melaninogenicus ss. intermedius was strongly correlated with plasma levels of estrogens and progesterone. No changes were observed in clinical parameters or the subgingival flora of non-pregnant subjects.

Pregnancy and specifically steroid hormones appear capable of influencing the normal bacterial flora and inducing alterations in the subgingival ecology.

(Accepted for publication July 26, 1979)

\section{Introduction}

Recent studies in humans have suggested that the subgingival bacterial flora associated with periodontal disease is composed of elevated proportions of certain Gramnegative microorganisms (Slots 1976, Newman \& Socransky 1977, Slots 1977b). These organisms are also found in lower numbers in gingival health and in gingivitis (van Palenstein Helderman 1975, Slots 1977a, Slots et al. 1978, Loesche \& Syed 1978). The determination of factors which induce or allow a shift in the bacterial flora found in gingival health may provide insights into the etiology of the transition from health to gingivitis and to periodontitis.

An increase in gingival inflammaton has been reported for several systemic conditions, such as puberty, menstruation, pregnancy, and stress, which are associated with fluctuations in the levels of serum steroids. Cross-sectional and longitudinal studies have consistently shown a gradual increase in gingivitis during pregnancy with apparent resolution following parturition (Löe \& Silness 1963, Silness \& Löe 1964, Hugoson 1970, Cohen et al. 1971). In all of the studies, plaque scores were essentially low and stable throughout pregnancy. The increase 
in gingivitis independent of a change in clinically detectable plaque mass led to the suggestion that altered steroid levels increased the inflammatory response to a given plaque challenge (Lindhe, Attstrom \& Bjorn 1968, Hugoson 1970, Lindhe, Hellden \& Lundgren 1972). No investigations of the bacteriology of plaque from pregnant subjects have been reported. This study monitored the gingival crevice microbial flora in pregnant and nonpregnant women to determine if gestation induces alterations in the gingival crevice flora and if these changes can be associated with pregnancy gingivitis.

\section{Clinical Methods}

Twenty women, age $20-33$, whose pregnancies were thought to be less than 13 weeks at the initial dental examination, were seen monthly until delivery and again post-partum in the University of Michigan Women's Hospital Obstetrics Clinic. Eleven nonpregnant women, age 22-36, were seen monthly for four consecutive months. Each control subject was asked to record the dates of her menstrual period so that each visit occurred at approximately the same stage in the menstrual cycle as the first visit. Preliminary studies suggested that a four month sampling period would be adequate for determining the stability over time of clinical and bacteriological evaluations in nonpregnant subjects. At the initial examination none of the subjects had any evidence of loss of periodontal attachment on probing. All subjects had moderate to good oral hygiene and had not received a dental prophylaxis for at least 6 months prior to the study. At each visit the Gingival Index (G.I., Löe \& Silness 1963) and the Plaque Index (Pl. I., Silness \& Löe 1964) were determined for the mesial of the maxillary right second premolar (Site 1) and of the mandibular left cuspid (Site 2) in each subject. An interproximal eval- uation of the bleeding score (B.S.) for each subject was determined by counting the interproximal sites which bled to any extent after gentle probing with a wooden interdental stimulator (Stim-u-dent ${ }^{\circledR}$ ). A maximum of 22 interproximal sites were available in each patient, mesial to the first molars. No distinction was made between spontaneous and induced bleeding.

Supragingival plaque was removed from both sample sites by means of a scaler and discarded. Subgingival plaque samples were taken from each site by means of a sterile curette and placed in a vial of reduced transport fluid without ethylenediaminetetraacetate (RTF, Loesche, Hockett \& Syed 1972).

\section{Bacteriology}

Plaque samples were taken into the anaerobic chamber (Aranki et al. 1969) and were dispersed by sonication ((Kontes Cell Disrupter, Syed \& Loesche 1978) and diluted in RTF. Dilutions were plated on selective and nonselective media by means of an automatic diluting and plating device (Spiral Systems, Bethesda, Md.).

Enriched Trypticase Soy Agar (ETSA) which consists of a trypticase soy agar and yeast extract base supplemented with sodium lactate $(600 \mu \mathrm{g} / \mathrm{ml})$, sodium succinate $(500 \mu \mathrm{g} / \mathrm{ml})$, sodium formate $(500 \mu \mathrm{g} / \mathrm{ml})$, potassium nitrate $(500 \mu \mathrm{g} / \mathrm{ml})$, cysteine (400 $\mu \mathrm{g} / \mathrm{ml})$, dithiothreitol $(100 \mu \mathrm{g} / \mathrm{ml})$, hemin $(1 \mu \mathrm{g} / \mathrm{ml})$, menadione $(1 \mu \mathrm{g} / \mathrm{ml})$ and $3 \%$ sheep blood was used for nonselective anaerobic and aerobic growth. Bacteroides melaninogenicus was quantitated by both ETSA and ETSA with $50 \mu \mathrm{g} / \mathrm{ml}$ kanamycin sulfate (Loesche, Hockett \& Syed 1971, Syed, Svanberg \& Svanberg 1979). The gelatin, metronidazole; cadmium sulfate (GMC) agar of Kornman and Loesche (1978) was used to quantitate Actinomyces viscosus and Actinomyces naeslundii. MM10 agar with $5 \%$ sucrose (Loesche et 
al. 1972) was used to quantitate Streptococcus sanguis.

Differential counts and biochemical characterization of isolates were keyed to those organisms currently thought to undergo proportional shifts associated with periodontal disease. These organisms are Actinomyces naeslundii, Actinomyces odontolyticus, Actinomyces viscosus, Bacteroides melaninogenicus ss. intermedius, $B$. melaninogenicus ss. melaninogenicus, Bacteroides asaccharolyticus, Bacteroides (Capnocytophaga) ochraceus, Fusobacterium nucleatum, Streptococcus sanguis, and surface translocating bacteria (STB).

From each medium, two precisely measured areas or sectors of the agar including more than 20 colonies per sector were quantitated by means of a binocular dissection microscope. The total number of colonies and the number of selected colony types were determined for each sector. Classification of isolates was based on colony morphology, Gram-stain morphology, motility by dark field microscopy, aerobic growth, indole production, esculin hydrolysis, nitrate reduction, nitrite reduction, gelatinase activity, catalase activity, $\mathrm{pH}$ in glucose broth, $\mathrm{pH}$ in glucose-1-phosphate broth, $\mathrm{pH}$ in mannitol broth, and acid end products by gas liquid chromatography.

Isolates were identified to the species level, where possible, using the classification scheme in Table 1. The scheme allowed many of the predominant organisms to be identified with a limited number of tests which were keyed to a presumptive identification based on characteristic colony morphology. The taxonomic scheme incorporated data from the Virginia Polytechnic Institute Anaerobe Laboratory Manual (4th Edition, 1977), Loesche \& Gibbons 1965, Holmberg \& Nord 1975, Holbrook, Duerden \& Deacon 1977, Duerden, Holbrook \& Collee 1976, Syed \& Loesche 1978 and Facklam 1977.
Steroid uptake by plaque samples

Duplicate $100 \mu 1$. portions of each dispersed plaque sample were incubated anaerobically with estradiol and progesterone to evaluate uptake of these substrates by the plaque sample.

The assay was carried out in round bottom plastic microtiter plates.

Into each well was placed:

$50 \mu$ Estradiol (4-C14, Amersham-Searle, $1.82 \times 10^{-3} \mu$ moles $\left./ 50 \mu \mathrm{l}\right)$

$50 \mu 1$ Progesterone $\left(4-\mathrm{C}^{14}, 3.40 \times 10^{-3}\right.$ $\mu$ moles $/ 50 \mu \mathrm{l}$ )

$50 \mu \mathrm{l}$ RTF + NADH $\left(1.64 \mathrm{X}_{10^{-4}}^{-4} \mathrm{M}\right)$

$+\mathrm{MgCl}_{2}\left(1.00 \times 10^{-4} \mu \mathrm{M}\right)$

$100 \mu 1$ dispersed plaque suspension. Controls contained RTF instead of plaque or plaque heat-killed at $80^{\circ} \mathrm{C}$ for thirty minutes.

After 60 minutes incubation at $37^{\circ} \mathrm{C}, 1$ $\mu l$ samples were removed by means of a Hamilton syringe with a Cheney Adaptor and the samples were spotted on silica gel thin-layer chromatography (TLC) sheets. TLC plates were removed from the anaerobic chamber, developed vertically in chloroform/acetaldehyde $(80 / 20 \mathrm{v} / \mathrm{v})$, visualized with vanillin $(0.5 \%)$ in $1 \% \mathrm{H}_{2} \mathrm{SO}_{4}$ and ethanol (1:4) (modified procedure of Matthews 1963). The estradiol and progesterone spots were identified by comparisons with standards and were cut out and quantitated by means of liquid scintillation counting. The quantities of $\mathrm{C}^{14}$-estradiol and $\mathrm{C}^{14}$-progesterone in the assay wells after 60 minutes were subtracted from RTF control wells to calculate the amount of substrate utilized by the plaque samples. Substrate uptake was expressed as moles per $\mu \mathrm{g}$ of bacterial protein (fluorescamine protein assay, Weigele et al. 1972) in the assay well.

\section{Serum steroid determination}

Thirty $\mathrm{ml}$. of peripheral blood was removed from the median vein in the ante- 
Table 1

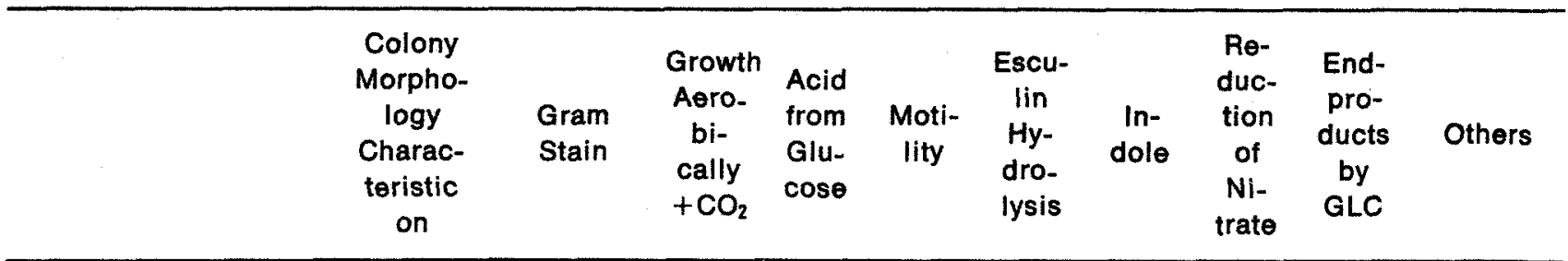

\section{Gram-Positive Rods}

Actinomyces

israelii

naeslundii

viscosus

Bacillus

Propionibacterium acnes

Clostridium

Arachinia

Eubacterium

Gram-Positive Coccl Micrococci

Streptococci

miteor

mutans

sanguis

salivarius

Peptostreptococci

Peptococci

Gram-Negative Rods

Bacteroides

asaccharolyticus

melaninogenicus

ss. intermedius

ss. melanino-

genicus

corrodens

oralis

ochraceus

(Capnocytophaga)

Eikenella

corrodens

Fusobacterium nucleatum

Selenomonas sputigena

Campylobacter sputorum

\section{G+}

branching

white con-

vex on

GMC

red convex

on ETSA

white con-

vex on

GMC

spores

branching

spores

$\begin{array}{ll}- & + \\ + & +\end{array}$

$$
\begin{array}{lll} 
\pm & - & + \\
+ & - & +
\end{array}
$$

ALS Gelatinase$\mathrm{MOH}+$

Catalase+

Gelatinase +

Catalase +

Gelatinase-1

Catalase +

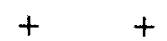

$-\quad+$

- +

$+\quad+$ $\mathrm{mm} 10$

heaped

$\mathrm{mm} 10$ ad-

herent

$\mathrm{mm} 10 \mathrm{mu}$ -

coid
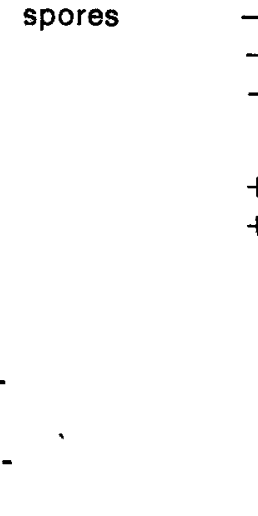

ETSA

ETSA

ETSA

ETSA

ETSA

ETSA

ETSA

$$
\begin{array}{llll}
- & - & + & \mathrm{AP} \\
- & - & + & \mathrm{APB}
\end{array}
$$

Catalase$\mathrm{MOH}-$ $\mathrm{MOH}+$

$\mathrm{MOH}-$

$\mathrm{MOH}-$

$A^{*}$ Catalase-

A $^{*}$ Catalase+

$A P^{*}$

SA

SA

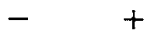$$
\text { - } \quad+
$$$$
+\quad S A
$$

urease + oxidase + $-\quad+$

$+$

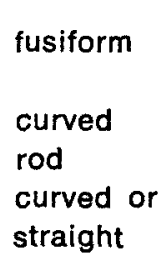
nitrite reduction 
Table 1 (contd.)

\begin{tabular}{|c|c|c|c|c|c|c|c|c|c|c|}
\hline & $\begin{array}{l}\text { Colony } \\
\text { Morpho- } \\
\text { logy } \\
\text { Charac- } \\
\text { teristic } \\
\text { on }\end{array}$ & $\begin{array}{l}\text { Gram } \\
\text { Stain }\end{array}$ & $\begin{array}{l}\text { Growth } \\
\text { Aero- } \\
\text { bi- } \\
\text { cally } \\
+\mathrm{CO}_{2}\end{array}$ & $\begin{array}{l}\text { Acid } \\
\text { from } \\
\text { Glu- } \\
\text { cose }\end{array}$ & $\begin{array}{c}\text { Moti- } \\
\text { lity }\end{array}$ & $\begin{array}{l}\text { Escu- } \\
\text { lin } \\
\text { Hy- } \\
\text { dro- } \\
\text { lysis }\end{array}$ & $\begin{array}{l}\text { In- } \\
\text { dole }\end{array}$ & $\begin{array}{c}\text { Re- } \\
\text { duc- } \\
\text { tion } \\
\text { of } \\
\mathrm{Ni-} \\
\text { trate }\end{array}$ & $\begin{array}{l}\text { End- } \\
\text { pro- } \\
\text { ducts } \\
\text { by } \\
\text { GLC }\end{array}$ & Others \\
\hline \multicolumn{11}{|c|}{ Gram-Negative Cocel } \\
\hline Neisseria & & & + & + & & & & & & catalase + \\
\hline $\begin{array}{l}\text { Veillonella } \\
\text { alcalescens }\end{array}$ & & & - & - & & - & - & + & AP & catalase- \\
\hline parvula & & & - & - & & - & - & + & AP & catalase + \\
\hline
\end{tabular}

* others variable

cubital fossa of each subject 3 times during pregnancy and again post-partum. Blood samples were taken at each visit from five of the control subjects. The peripheral blood leukocytes were used to monitor the in vitro lymphocyte transformation response to the predominant microorganisms found in the subgingival plaque during pregnancy and will be reported separately. Plasma levels of progesterone and estrogens, including both estradiol and estrone, were determined by radioimmunoassay as described by Yalow and Berson (1971) using reagents obtained from New England Nuclear (NEA-044,042).

\section{Statistical analysis}

Differences between the mean data from different time periods were evaluated by means of a paired $t$-test. The strength of the linear relationship between parameters was evaluated by computing the productmoment correlation coefficient, including a t-test of the null hypothesis that the population correlation was zero.

\section{Results}

Clinical measurements revealed an increase in gingivitis in the pregnant subjects (PG) as indicated by gingival bleeding. The mean number of bleeding sites per patient in- creased significantly between $13-28$ weeks gestation, with the peak at 21-24 weeks (Fig. 1). The mean Gingival Index at Site 1 and Site 2 increased significantly ( $p<0.05$, pairwise t-test) from 1.16 initially to between 1.44 and 1.61 by $13-28$ weeks. The mean Plaque Index at both sites (1.13) was essentially unchanged throughout the pregnancy and post-partum. Clinical parameters (B.S., GI and Pl I) in the nonpregnant (NP) group did not change during the 4month sampling period, with a mean bleeding score of $3.7 \pm 0.1$ (standard error), mean GI of $1.17 \pm 0.18$, and mean Pl I of $1.00 \pm 0.36$.

In the second trimester the mean number of bleeding sites and the GI were signifi-

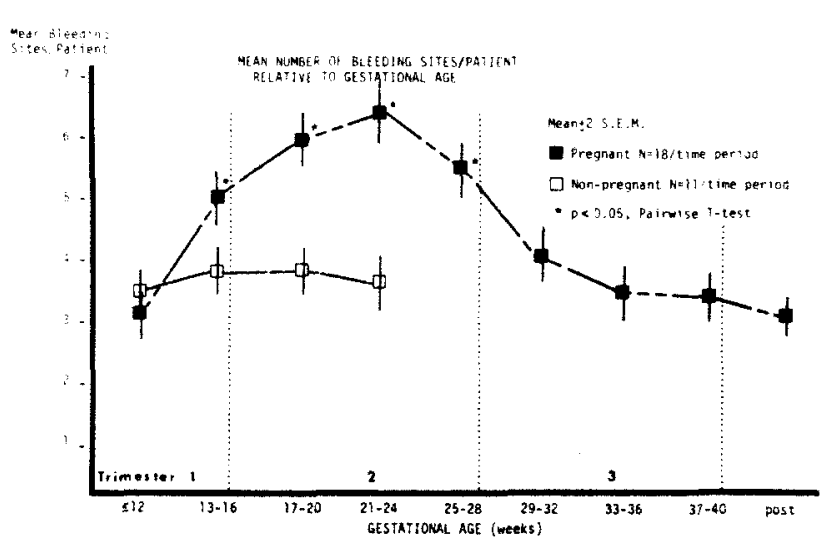

Fig. 1. Mean number of interproximal gingival bleeding sites in the entire mouth for pregnant and nonpregnant subjects. A maximum of twenty sites per subject was available for scoring. 
Table 2

Bacteriological Findings in Pregnant Subjects

\section{Sampling Time}

\begin{tabular}{|c|c|c|c|c|}
\hline Organism & $\begin{array}{c}\text { First Trimester } \\
\text { ( } \leq 13 \text { weeks) }\end{array}$ & $\begin{array}{c}\text { Second Trimester } \\
\text { (21-24 weeks) }\end{array}$ & $\begin{array}{l}\text { Third Trimester } \\
\text { (33-36 weeks) }\end{array}$ & Post-Partum \\
\hline $\begin{array}{l}\text { Total Count } \\
\left(\times 10^{6}\right)\end{array}$ & $11.00 \pm 15.52^{1}$ & $7.30 \pm 13.60$ & $4.35 \pm 11.00$ & $10.21 \pm 12.35$ \\
\hline $\begin{array}{l}\text { Anaerobe/Aerobe } \\
\text { Ratio }{ }^{2}\end{array}$ & $5.94 \pm 0.36$ & $19.86 \pm 2.29$ & $6.20 \pm 0.52$ & $6.14 \pm 0.53$ \\
\hline A. naeslundii $(\%)^{3}$ & $2.65 \pm 6.01$ & $4.87 \pm 5.33$ & $4.88 \pm 5.67$ & $1.78 \pm 5.51$ \\
\hline A. odontolyticus $(\%)$ & $2.36 \pm 3.18$ & $4.35 \pm 4.12$ & $1.99 \pm 3.14$ & $1.97 \pm 3.18$ \\
\hline A. viscosus $(\%)$ & $5.80 \pm 3.40$ & $7.62 \pm 4.86$ & $1.70 \pm 3.24$ & $4.32 \pm 3.78$ \\
\hline B. asaccharolyticus $(\%)$ & $2.24 \pm 4.48$ & $7.65 \pm 10.84$ & $2.83 \pm 5.60$ & $2.52 \pm 5.02$ \\
\hline $\begin{array}{l}\text { B. melaninogenicus } \\
\text { ss. intermedius }(\%)\end{array}$ & $2.43 \pm 2.19$ & $10.10 \pm 7.74$ & $3.20 \pm 4.00$ & $2.18 \pm 3.47$ \\
\hline $\begin{array}{l}\text { B. (Capnocytophaga) } \\
\text { ochraceus }(\%)\end{array}$ & $2.42 \pm 2.37$ & $7.21 \pm 7.45$ & $2.94 \pm 3.99$ & $2.04 \pm 2.29$ \\
\hline F. nucleatum $(\%)$ & $4.80 \pm 4.42$ & $7.30 \pm 6.48$ & $4.78 \pm 6.56$ & $4.39 \pm 4.66$ \\
\hline S. sanguis $(\%)$ & $19.00 \pm 10.42$ & $26.32 \pm 8.04$ & $19.25 \pm 7.23$ & $22.16 \pm 8.46$ \\
\hline
\end{tabular}

1. Mean \pm 2 standard errors of the mean $N=36 /$ time period.

2. Ratio of the total number of organisms growing ana erobically to the total number growing aerobically on primary isolation.

3. Percentage of total colony forming units.

$\square$ Values within box are significantly different ( $p<0.01$, pairwise t-test) from all other values in row.

\section{Table 3}

Bacteriological Findings in Non-Pregnant Subjects During Four Successive Samplings

\begin{tabular}{lcccc}
\hline \multicolumn{1}{c}{ Sampling Time } \\
\multicolumn{1}{c}{ Organism } & 0 & 4 Weeks & 8 Weeks & Weeks \\
\hline $\begin{array}{l}\text { Total Count } \\
\quad\left(\times 10^{6}\right)\end{array}$ & $3.50 \pm 7.631$ & $4.25 \pm 9.65$ & $3.20 \pm 7.15$ & $3.10 \pm 7.60$ \\
$\begin{array}{l}\text { Anaerobe/Aerobe } \\
\quad \text { Ratio }\end{array}$ & $3.72 \pm 0.76$ & $4.25 \pm 0.32$ & $5.43 \pm 0.48$ & $4.51 \pm 0.55$ \\
A. naeslundii (\%) & $4.60 \pm 8.30$ & $6.04 \pm 7.45$ & $2.34 \pm 3.98$ & $2.32 \pm 4.06$ \\
A. odontolyticus (\%) & $0.49 \pm 1.67$ & $0.53 \pm 2.07$ & $0.93 \pm 4.50$ & $1.25 \pm 4.40$ \\
A. viscosus (\%) & $5.96 \pm 2.80$ & $4.45 \pm 3.64$ & $3.89 \pm 2.64$ & $4.44 \pm 3.20$ \\
B. asaccharolyticus (\%) & $0.70 \pm 0.60$ & $0.52 \pm 0.68$ & $0.54 \pm 0.55$ & $0.72 \pm 0.53$ \\
B. melaninogenicus & $1.98 \pm 1.81$ & $2.65 \pm 1.78$ & $2.32 \pm 1.90$ & $2.83 \pm 1.87$ \\
$\quad$ ss. intermedius (\%) & & & & \\
B. (Capnocytophaga) & & & & \\
$\quad$ ochraceus (\%) & $3.70 \pm 2.97$ & $3.12 \pm 3.90$ & $3.21 \pm 3.56$ & $3.64 \pm 3.99$ \\
F. nucleatum (\%) & $2.24 \pm 2.98$ & $3.98 \pm 5.05$ & $1.50 \pm 2.50$ & $2.19 \pm 2.45$ \\
S. sanguis (\%) & $18.46 \pm 7.46$ & $18.73 \pm 8.22$ & $22.27 \pm 8.04$ & $21.74 \pm 7.92$ \\
\hline
\end{tabular}

1. Mean \pm 2 standard errors of the mean $N=22 /$ time period

2. Ratio of the total number of organisms growing an aerobically to the total number growing aerobically on primary isolation.

3. Percentage of total colony forming units. 
cantly higher $(\mathrm{p}<0.05$, Student's $t$-test $)$ than those values in the non-pregnant subjects. The Pl I exhibited no differences between groups at any time period.

A total of 416 subgingival plaque samples were cultured during the course of the study. A minimum of 36 samples from the pregnant subjects were analyzed at each of the 9 time periods. A minimum of 22 samples from the nonpregnant subjects were evaluated monthly for four months. Bacterial changes over time were evaluated by means of pairwise t-tests comparing the bacteriology at each time period with the initial sampling period. Statistically significant changes were observed in the pregnant subjects for the anaerobe/aerobe ratio and the proportions of $B$. melaninogenicus ss. intermedius.

Table 2 gives the bacterial findings representative of the trimesters of gestation and the post partum samples. Data for the four samples in the nonpregnant subjects are in Table 3 .

In the pregnant women the total count of colony forming units (CFU) per sample was $4-11 \times 10^{6}$ at all time periods. Total counts from NP sites were in the range $3-5 \times 10^{6}$ at all sampling periods (Tables 2,3).

The anaerobe/aerobe ratios for NP samples were stable over time in the range of 4-7 (Fig. 2), but the ratios for the PG samples increased significantly at the second sampling period. The initial mean anaerobe/aerobe ratio of 5.9 increased to approximately 35 at 13-20 weeks and remained at an elevated level through 24 weeks (Fig. 2). Samples returned to initial values by $25-28$ weeks and remained at that level through the postpartum sample.

Recovery of B. melaninogenicus ss. intermedius from the PG group increased significantly $(\mathrm{p}<0.05)$ as pregnancy progressed. The mean recovery of $B$. melaninogenicus ss. intermedius went from $2.2 \%$ of the initial cultivable flora to $10.1 \%$ at $21-24$

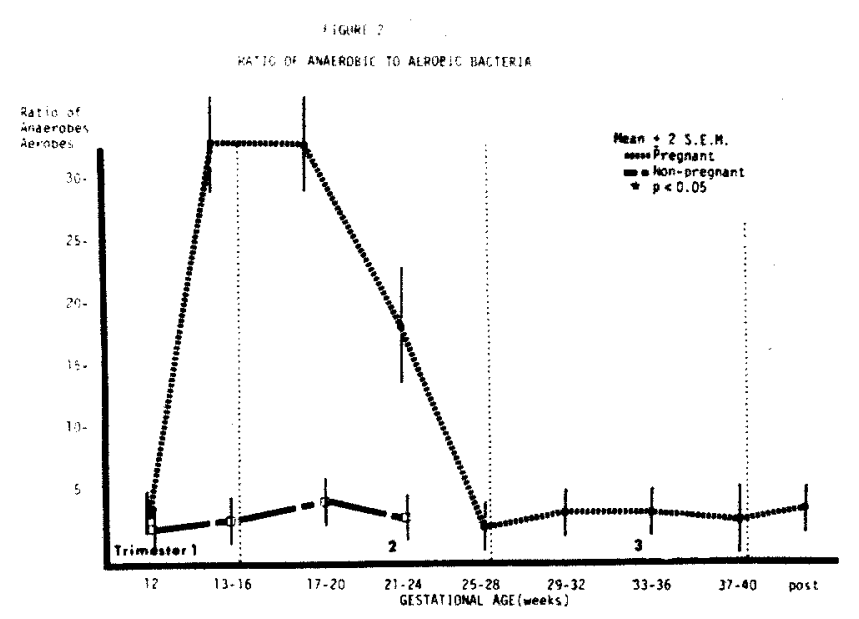

Fig. 2. Ratio of the total number of colony forming units on a nonselective medium (ETSA) incubated anaerobically to the total number on the same medium incubated aerobically.

weeks (Fig. 3a, Table 2). The proportions of this organism decreased by 29-32 weeks and returned to the initial levels at the postpartum sample. No similar change was observed in the NP samples.

The mean proportions of $B$. asaccharolyticus increased at 21-28 weeks, but the variation was great and statistical significance at $\mathrm{p}<0.05$ was not achieved (Fig. $3 \mathrm{~b}$, Table 2). The apparent increase in this organism was due to two subjects from whom very high levels $(50-65 \%)$ were recovered at 21-28 weeks. Bacteroides (Capnocytophaga) ochraceus also appeared to increase at 21-28 weeks (Fig. 3c, Table 2), but the changes were not statistically significant by pairwise t-tests.

Actinomyces viscosus exhibited a significant $(\mathrm{p}<0.05)$ decrease in the mean recovery from samples at 33-36 weeks (Fig. $3 \mathrm{~d}$, Table 2). The initial mean level of $5.8 \%$ declined to $1.7 \%$ of the cultivable flora. In the post partum samples $A$. viscosus accounted for $4.3 \%$ of the flora. Other bacteria which were found consistently in all subjects did not change significantly during pregnancy (Table 2). At all sampling periods from both pregnant and nonpregnant subjects $A$. naeslundii repre:sented $4.9 \%$ of the cultivable flora, $F . n u$ - 

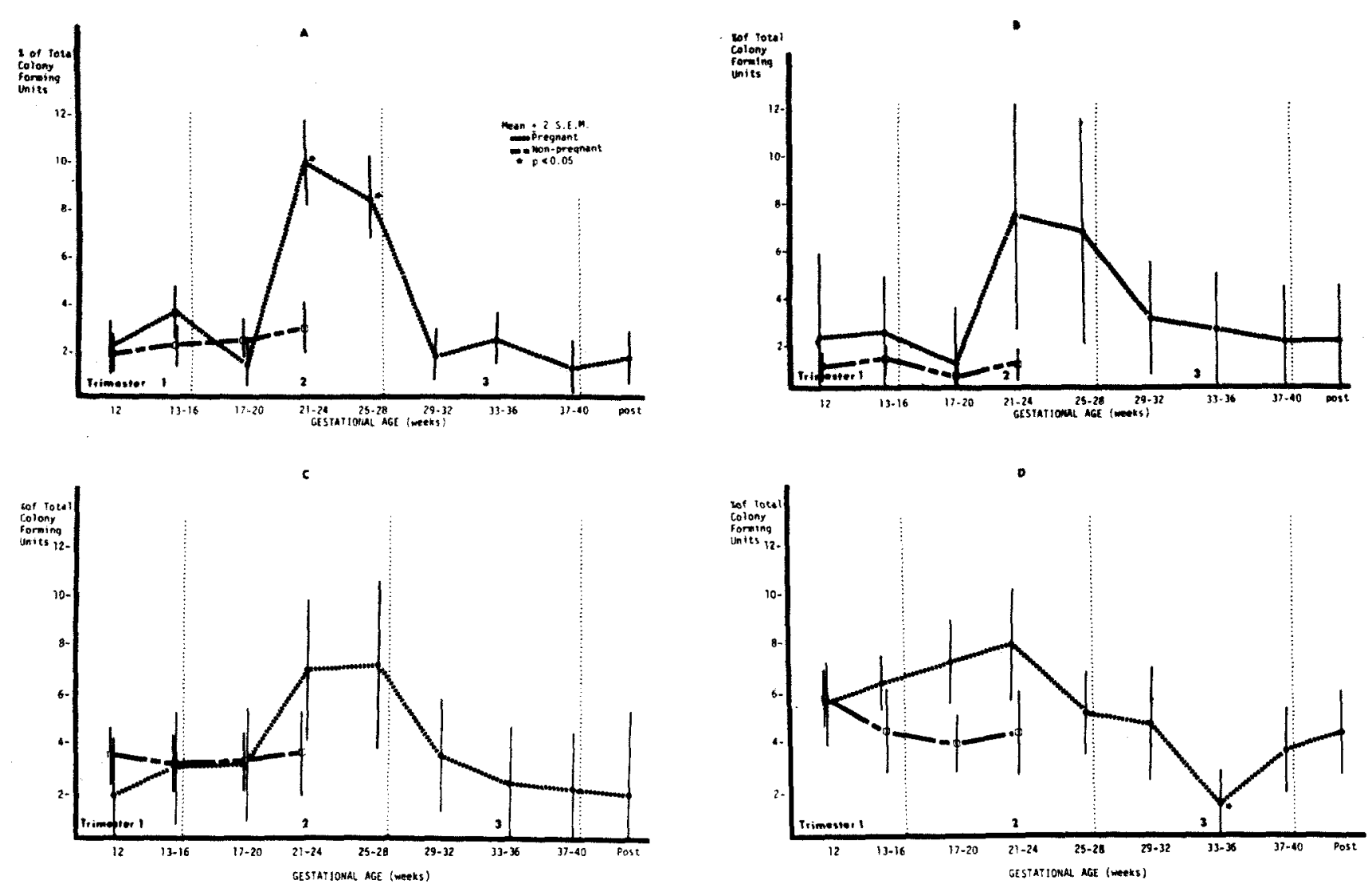

Fig. 3. Recovery of each indicated organism as a percentage of the total colony forming units on a nonselective medium (ETSA) incubated anaerobically.
A. Recovery of Bacteroides melaninogenicus ss. interm edius as evaluated on a nonselective medium (ETSA).
B. Recovery of Bacteroides asaccharolyticus as evaluated on ETSA.
C. Pecovery of Bacteroides (Capnocytophaga) ochraceus as evaluated on ETSA.
D. Recovery of Actinomyces viscosus as evaluated on gelatin-metronidazole-cadmium sulfate medium.

cleatum $5.0 \%$ of the flora, A. odontolyticus $3.3 \%$ of the flora, S. sanguis $20.5 \%$ of the flora, and Veillonella species $4.8 \%$ of the flora. Gram positive anaerobic rods represented $10-15 \%$ of the flora except for low levels $(3.4 \%)$ recovered in the second trimester. Great variability was observed in recovery of individual species but most samples included at least two of the following: A. israelii, A. odontolyticus, Propionibacterium acnes, and Eubacterium species.

No significant changes were observed in any of the clinical or bacteriological parameters from the NP group (Table 3).

In the second trimester samples from the PG group, the anaerobe/aerobe ratio and the proportions of $B$. melaninogenicus ss. intermedius and $B$. asaccharolyticus differed significantly $(p<0.05$, Student's t- test) from the NP group. No other group differences were observed.

At the initial sampling period (12 weeks) Gram-negative anaerobic rods accounted for approximately $10 \%$ of the total flora. At the time of maximum detectable bleeding (21-24 weeks) the Gram-negative anaerobic rods had increased to $39 \%$ of the flora. The proportions of the Gram-positive facultative organisms, which included primarily Actinomyces species and Streptococcus sanguis remained unchanged throughout pregnancy. Although no single species decreased significantly during pregnancy, Gram positive anaerobic rods and Gram negative anaerobic cocci together accounted for $19.7 \%$ of the flora initially and decreased to $5.4 \%$ of the flora in the second trimester. 


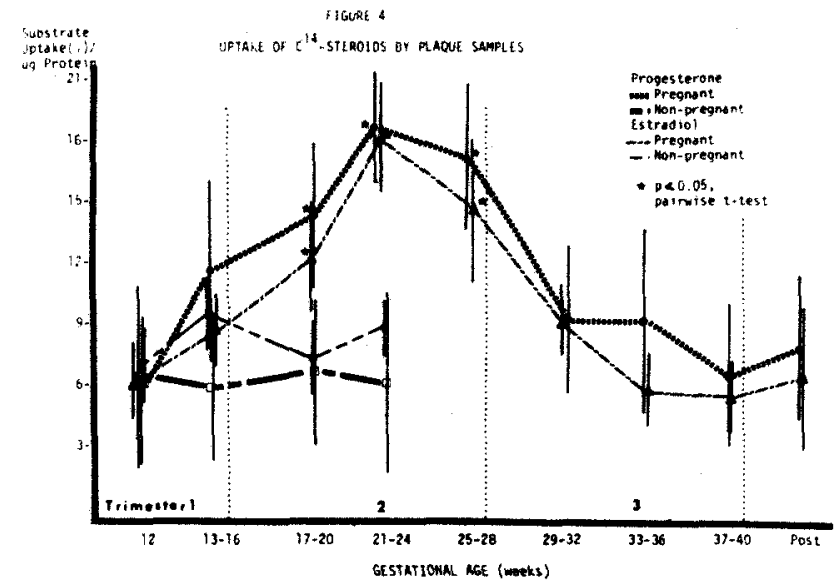

Fig. 4. Uptake of $\mathbf{C}^{14}$-esstradiol and $\mathbf{C}^{14}$-progesterone by plaque samples from pregnant and non-pregnant subjects. Data are expressed as substrate taken up relative to total substrate added.

\section{Steroid uptake by plaque samples}

The uptake of estradiol by PG plaque samples increased significantly $(\mathrm{p}<0.05)$ from $4.4 \%$ of the available steroid taken up initially to $18.1 \%$ at $21-24$ weeks (Fig. 4). After that time estradiol uptake decreased so that by 29-32 weeks the values had returned to those seen initially.

Progesterone uptake by PG plaque samples increased significantly $(\mathrm{p}<0.05)$ from an initial mean uptake of $4.1 \%$ to $18.4 \%$ by 21-24 weeks (Fig. 4). Uptake of estradiol or progesterone by plaque samples from the NP group did not change during the experimental period (Fig. 4). Negligible steroid uptake occurred with heat killed plaque or when the reaction mixtures were incubated at $4^{\circ} \mathrm{C}$.

In the pregnant subjects, mean plasma estrogens ranged from 5.8 to $6.4 \mathrm{ng} / \mathrm{ml}$. in the first and second trimesters and postpartum. The mean estrogen level in the third trimester was $21.2 \mathrm{ng} / \mathrm{ml}$. Progesterone ranged from 24.2 to $41.5 \mathrm{ng} / \mathrm{ml}$. except for the third trimester samples which averaged $200.4 \mathrm{ng} / \mathrm{ml}$. In the nonpregnant subjects mean estrogen levels ranged from 0.16 to $0.20 \mathrm{ng} / \mathrm{ml}$. and mean progesterone levels ranged from 6.28 to $8.48 \mathrm{ng} / \mathrm{ml}$.
These values are consistent with previous reports which used comparable techniques (Abraham et al. 1971, Wu \& Lundy 1971).

In the PG group, recovery of $B$. melaninogenicus ss. intermedius had a positive correlation ( $\mathrm{r}=0.93, \mathrm{p}<0.01$ ) with progesterone levels at $25-28$ weeks and a positive correlation $(r=0.55, \mathrm{p}<0.05)$ with estradiol at 21-24 weeks. F. nucleatum had a positive correlation $(0.67, \mathrm{p}<0.05)$ with serum progesterone at 33-34 weeks, and $B$. (Capnocytophaga) ochraceus had a positive correlation ( $r=0.68$ ) with serum estradiol at 21-24 weeks. B. asaccharolyticus exhibited a significant negative correlation with serum estradiol levels at 17-20 weeks $(\mathrm{r}=-0.80, \mathrm{p}<0.05)$ and at $21-24$ weeks $(r=-0.68)$. The plaque species in the NP group presented no significant correlations with serum steroid levels.

\section{Discussion}

In the present study gingivitis increased significantly between 13-28 weeks gestation and then decreased. Cross-sectional studies (Löe \& Silness 1963, Silness \& Löe 1964) described a gradual increase in gingivitis during pregnancy with apparent resolution following parturition. One longitudinal study (Hugoson 1970) confirmed that pattern, and another (Cohen et al. 1971) observed a statistically significant increase in gingivitis at six months gestation and a slight decrease in the third trimester. In previous studies (Löe \& Silness 1963, Cohen et al. 1971), plaque remained essentially constant throughout the pregnancy. Hugoson (1970) reports, however, a decrease in the Plaque Index in the third trimester. In the present study the Plaque Index did not fluctuate but the viable count of organisms recovered from the samples showed a marked decline in the later stage of pregnancy.

The subgingival flora changed to a more anaerobic flora as pregnancy progressed. 
The anaerobe/aerobe ratio increased significantly at an early stage of pregnancy (1316 weeks) and remained high until the third trimester. The only organism whose proportions increased significantly during pregnancy was $B$. melaninogenicus ss. intermedius. At the peak of gingival bleeding the plaque proportions of this organism were five-fold greater than initial levels.

Minor increases were observed in other Gram-negative anaerobic rods, such that at 21-24 weeks all Gram-negative anaerobic rods together accounted for $39 \%$ of the flora. This is greater than the proportions of Gram-negative anaerobes reported for chronic gingivitis i.e. 26-29\% (Slots et al. 1978, van Palenstein Helderman 1975), experimental gingivitis i.e. $20 \%$ (Loesche \& Syed 1978), and less than the levels in juvenile periodontitis i.e. 55-73\% (Slots 1976, Newman \& Socransky 1977).

The increase during pregnancy in $B$. meloninogenicus ss. intermedius appears to be associated with elevations in systemic levels of estradiol and progesterone. This is based on the finding that there was increased steroid uptake by plaque samples which paralleled increased plaque proportions of $B$. melaninogenicus ss. intermedius. In addition, serum levels of estradiol and progesterone showed a positive correlation with plaque levels of $B$. melaninogenicus ss. intermedius until the late stages of pregnancy. Subsequent pure culture studies have shown that estradiol or progesterone can substitute for menadione as an essential growth factor in $B$. melaninogenicus ss. intermedius and $B$. melaninogenicus ss. melaninogenicus but not in $B$. asaccharolyticus or B. (Capnocytophaga) ochraceus (Kornman \& Loesche 1979).

The effects of endogenous steroids on the normal microbial flora are essentially unknown. Ovarian function has been associated with changes in the vaginal tract bacterial flora, with a cyclic increase in aciduric lactobacilli being the most prominent finding (Weinstein et al. 1936). A recent study in rats (Larsen, Markovetz \& Galask 1977) observed that anaerobic bacteria became nondetectable in genital samples after animals were ovariectomized. Exogenous estradiol administered to ovariectomized rats produced a prolonged increase in vaginal bacterial levels from $5 \times 10^{4}$ to $1 \times 10^{8}$ organisms/sample. Other investigations have demonstrated that steroid hormones inhibit the growth of pure cultures of a variety of Gram-positive bacteria (Yotis 1967), as well as Neisseria gonorrhoeae (Morse \& Fitzgerald 1974).

Although it is difficult to assess the involvement of specific bacteria in pregnancy gingivitis, at the peak of gingival bleeding Gram-negative anaerobic rods had increased four-fold over initial levels.

Of perhaps greater importance is the observation that shifts in endogenous steroid levels may have a significant influence on the indigenous gingival crevice flora. Since the disease-associated microflora appears to represent an alteration in the normal subgingival ecology, the identification of factors which induce a shift in the flora may be of importance in determining what initiates periodontal disease. Subsequent reports will describe a potential biochemical mechanism for steroid interaction with Bacteroides species, and the cell-mediated immune response to oral antigens during pregnancy.

\section{Acknowiedgements}

The investigation was supported by National Institutes of Dental Research Grants No. DE 03011 and DE 02731. KSK was a recipient of N.I.D.R. fellowship DE 00013.

We would like to thank Dr. Robert Willson and Dr. Jan Schneider of the Department of Obstetrics and Gynecology for their assistance in providing patients and 
facilities. The technical assistance of Dr. Tom Ruprecht was very much appreciated.

\section{References}

Abraham, G. E., Swerdloff, R., Tulchinsky, D. \& Odell, W. D. 1971. Radioimmunoassay for plasma progesterone. Journal of Clinical Endocrinology and Metabolism 32: 619-623.

Aranki, A., Syed, S. A., Kenney, E. B. \& Freter, R. 1969. Isolation of anaerobic bacteria from human gingiva and mouse cecum by means of a simplified glove box procedure. Applied Microbiology 17: 568-576.

Cohen, D., Shapiro, J., Friedman, L., Kyle, G. \& Franklin, S. 1971. A longitudinal investigation of the periodontal changes during pregnancy and fifteen months postpartum. Part II. Journal of Periodontology 42: 653.

Duerden, B. I., Holbrook, W. P. \& Collee, J. G. 1976. The characterization of clinically important Gram-negative anaerobic bacilli ty conventional bacteriological tests. Journal of Applied Bacteriology 40: 163-188.

Facklam, R. R. 1977. Physiological differentiation of viridans Streptococci. Journal of Clinical Microbiology 5: 184-201.

Holbrook, W. P., Duerden, B. I. \& Deacon, A. G. 1977. The classification of Bacteroides melaninogenicus and related species. Journal of Applied Bacteriology 42: 259-273.

Holmberg, K. \& Nord, C-E. 1975. Numerical taxonomy and laboratory identification of Actinomyces and Arachnia and some related bacteria. Journal of General Microbiology 91: 17-44.

Hugoson, A. 1970. Gingival inflammation and female sex hormones. Journal of Periodontal Research (Suppl.) 5.

Kornman, K. S. \& Loesche, W. J. 1978. A new medium for the isolation of Actinomyces viscosus and Actinomyces naeslundii from human dental plaque. Journal of Clinical Microbiology 7: 514-518.

Kornman, K. S. \& Loesche, W. J. 1979. Direct interaction of estradiol and progesterone with Bacteroides melaninogenicus. Journal of Dental Research 58: 107 Abstr. \#58.

Larsen, B., Markovetz, A. J. \& Galask, R. P. 1977. Role of estrogen in controlling the genital microflora of female rats. Applied and Environmental Microbiology 34: 534 540.

Lindhe, J., Attstrom, R. \& Bjorn, A-L. 1968. Influence of sex hormones on gingival exu- dation in dogs with chronic gingivitis. Journal of Periodontal Research 3: 279-283.

Lindhe, J., Héllden, L. \& Lundgren, D. 1972. Exudation and leukocyte emigration in progesterone and estrogen treated rats. Scandinavian Journal of Dental Research 80: 434 439.

Löe, H. \& Silness, J. 1963. Periodontal disease in pregnancy I. Prevalence and severity. Acta Odontologica Scandinavia 21: 533-551.

Loesche, W. J. \& Gibbons, R. J. 1965. A practical scheme for identification of the most numerous oral Gram-negative anaerobic rods. Archives of Oral Biology 10: 723-725.

Loesche, W. J., Hockett, R. \& Syed, A. A. 1971. Evaluation of Kanamycin as an aid in the isolation of Bacteroides melaninogenicus from dental plaque. Archives of Oral Biology 16: 813-815.

Loesche, W. J., Hockett, R. \& Syed, S. A. 1972. The predominant cultivable flora of tooth surface plaque removed from institutionalized subjects. Archives of Oral Biology 17: 1311-1325.

Loesche, W. J. \& Syed, S. A. 1978. Bacteriology of human experimental gingivitis. II. Effect of plaque and gingivitis score. Infection and Immunity 21: 830-839.

Matthews, J. S. 1963. Color reagent for steroids in thin-layer chromatography. Biochimica et Biophysica Acta 69: 163-165.

Morse, S. A. \& Fitzgerald, T. J. 1974. Effect of progesterone on Neisseria gonorrhoeae. Infection and Immunity 10: 1370-1377.

Newman, M. G. \& Socransky, S. S. 1977. Predominant cultivable microbiota in periodontosis. Journal of Periodontal Research 12: 120-128.

Silness, J. \& Löe, H. 1964. Periodontal disease in pregnancy. II. Correlation with oral hygiene and periodontal condition. Acta Odontologica Scandinavia 22: 121-135.

Slots, J. 1976. The predominant cultivable organisms in juvenile periodontitis. Scandinavian Journal of Dental Research 84: 1-10.

Slots, J. 1977a. Microflora in the healthy gingival sulcus in man. Scandinavian Journal of Dental Research 85: 247-254.

Slots, J. 1977b. The predominant cultivable microflora of advanced periodontitis. Scandinavian Journal of Dental Research 85: 114121.

Slots, J., Möenbo, D., Langebaek, J. \& Frandsen, A. 1978. Microbiota of gingivitis in man. Scandinavian Journal of Dental Research 86: 174-181. 
Syed, S. A. \& Loesche, W. J. 1978. Bacteriology of human experimental gingivitis: Effect of plaque age. Infection and Immunity 21: 821-829.

Syed, S. A., Svanberg, M. \& Svanberg, G. 1979. Predominant cultivable flora of gingivitis associated plaque of Beagle dogs. Manuscript in press. Journal of Periodontal Research.

van Palenstein-Helderman, W. H. 1975. Total viable count and differential counts of vibrio (Campylobacter) spurtorum, Fusabacterium nucleatum, Selenomonas sputigena, Bacteroides ochraceus, and Veillonella in the inflamed and non-inflamed human gingival crevice. Journal of Periodontal Research 10: 294-301.

Weigele, M., DeBernardo, S. L., Tengi, J. P. \& Leimgruber, W. 1972. A novel reagent for the fluorometric assay of primary amines. Journal of the American Chemical Society 94: 5927-5928.

Weinstein, L., Bogin, M., Howard, J. H. \&
Finkelstone, B. B. 1936. A survey of the vaginal flora at various ages with special reference to the Doderlein Bacillus. American Journal of Obstetrics and Gynecology 32: 211-218.

Wu, C. H. \& Lundy, L. E. 1971. Radioimmunoassay of plasma estrogens. Steroids 18: 91-96.

Yalow, R. S. \& Berson, S. A. 1971. Principles of Competitive Protein-Binding Assays, Chapter 1, Odell, W. D. and Daughaday (eds.) Philadelphia: J. B. Lippincott Co.

Yotis, W. W. 1967. In vivo and in vitro action of norethindrone on staphylococci. Journal of Bacteriology 94: 1353-1358.

Address:

Department of Periodontics

University of Connecticut Health Center

School of Dental Medicine

Farmington, Connecticut 06032

U.S.A. 
This document is a scanned copy of a printed document. No warranty is given about the accuracy of the copy. Users should refer to the original published version of the material. 